\title{
Effects of Placement Conditions on Decomposition of Municipal Solid Wastes in Cold Regions
}

\author{
J. L. Hanson ${ }^{1}$, N. Yesiller ${ }^{2}$, K. A. Howard ${ }^{3}$, W.-L. Liu ${ }^{4}$, and S. P. Cooper ${ }^{5}$ \\ ${ }^{1}$ Civil and Environmental Engineering Department, California Polytechnic State University, San Luis \\ Obispo, CA 93407-0353, Tel: (805) 756 6227, E-mail: jahanson@calpoly.edu. \\ ${ }^{2} 590$ Bluerock Dr., San Luis Obispo, CA 93401, Tel: (805) 547-1267, E-mail: nyesiller@gmail.com. \\ ${ }^{3}$ Municipality of Anchorage Solid Waste Services, 1111 E. 56th Avenue, Anchorage, AK 99519, Tel: \\ (907) 343-6279, E-mail: HowardKA@ci.anchorage.ak.us. \\ ${ }^{4}$ Department of Civil and Environmental Engineering, Wayne State University, 5050 Anthony Wayne \\ Dr., Detroit, MI 48202, Tel: (248) 719 0913, E-mail: lwl919@wayne.edu. \\ ${ }^{5}$ Municipality of Anchorage Solid Waste Services, 1111 E. 56th Avenue, Anchorage, AK 99519, Tel: \\ (907) 343-6274, E-mail: CooperSP@ci.anchorage.ak.us.
}

\section{Abstract}

The effects of placement practices on decomposition of wastes were investigated at Anchorage Regional Landfill (Anchorage, Alaska) since 2002. Temperatures and gas concentrations of wastes placed at various seasons were monitored. Wastes were placed at sub-freezing temperatures during cold seasons. Waste temperatures generally increased upon placement. High variation was observed in waste temperatures near the surface whereas steady temperatures were obtained at depth. High maximum stable temperatures resulted from warm placement conditions. Steady temperatures between approximately -1 to $+35^{\circ} \mathrm{C}$ were observed. The central portion of a frozen waste band (with a total initial thickness of $7 \mathrm{~m}$ at placement, currently between depths of approximately $8 \mathrm{~m}$ to $15 \mathrm{~m}$ ) remains frozen 2 years after placement. Both the top and bottom regions of the frozen waste band have thawed. Heat Content (HC) varied between -8.2 (for 2-year-old waste at a depth of $11.9 \mathrm{~m}$ in frozen wastes) to $+25.9^{\circ} \mathrm{C}$-day/day (for 13-year-old waste at a depth of $32 \mathrm{~m}$ for waste placed in summer). The measured frost depths in waste ranged from 0.7 to 1.3 $\mathrm{m}$ and were less than that for native soil at the landfill site. Instantaneous thermal gradients ranged from -73 to $+60^{\circ} \mathrm{C} / \mathrm{m}$. Gas concentrations were similar to air at the time of waste placement. Anaerobic decomposition conditions and onset of landfill gas production started within 3 to 4 years of placement for wastes placed during warm seasons. Virtually no decomposition or gas generation were observed in the frozen wastes. A 1-D numerical model was used to investigate distribution of temperatures for placement at varying temperatures and for varying lift thicknesses. It is recommended to minimize frozen lift thicknesses to obtain higher temperatures. 


\section{Introduction}

Placement of municipal solid wastes (MSW) in landfills remains as the primary method of waste disposal in the United States and many parts of the world. Decomposition and degradation of wastes in MSW landfills cause generation of gas, leachate, and heat. Generation of these byproducts is closely interrelated. For example, gas production is significantly affected by temperature. Temperature affects reaction rates and microbial population balance for decomposition of organic constituents (Hartz et al. 1982). The level of decomposition increases with temperature up to limiting values. Mesophilic and thermophilic methanogenic bacteria are primarily responsible for gas production. Optimum temperature ranges for the growth of these bacteria are 35 to $45^{\circ} \mathrm{C}$ and 50 to $60^{\circ} \mathrm{C}$ for mesophilic and thermophilic groups, respectively (Cecchi et al. 1993). Optimum temperature ranges for maximum gas production from wastes range between 34 and $41^{\circ} \mathrm{C}$ based on laboratory studies (DeWalle 1978, Hartz et al. 1982, Mata-Alvarez and MartinezViturtia 1986). A temperature of $43^{\circ} \mathrm{C}$ was identified as the optimum temperature for gas production at a landfill in England (Rees 1980). Significantly reduced gas production rates are expected at temperatures approximately below $20^{\circ} \mathrm{C}$ and above $75^{\circ} \mathrm{C}$ (Tchobanoglous et al. 1993).

Maximum reported waste temperatures generally varied from approximately 30 to $65^{\circ} \mathrm{C}$ and were observed within the middle one third depth to over one half depth of landfills with total waste heights of approximately 20 to $60 \mathrm{~m}$ (Yesiller et al. 2005). Climatic conditions, initial waste temperatures, and waste placement rates were determined to affect resulting waste temperatures (Hanson et al. 2005, Yesiller et al. 2005). Yesiller et al. (2005) presented a formulation for determination of heat generation in landfills as a function of climatic and operational conditions. Heat content $(H C)$ of wastes was determined as the difference between measured waste mass temperatures and unheated baseline waste temperatures over time at equivalent depths. The peak HCs were directly correlated to waste placement rates and initial waste temperatures. The HCs were also affected by precipitation. The peak HC increased with precipitation up to a value $2.3 \mathrm{~mm} /$ day and then decreased with further increase in precipitation.

Landfilling in cold regions presents specific operational challenges related to frozen material handling, freeze/thaw exposure to components of the waste containment system, and limited effectiveness for generation of landfill gas as an alternative energy source. The investigation described in this paper was conducted to evaluate the influence of a cold climate on the decomposition of municipal solid wastes. Field measurements were used to determine temperatures and gas composition at discrete locations throughout Anchorage Regional Landfill in Anchorage, Alaska. Measurements of temperature and gas composition were obtained over multiple years for evaluation of waste placement conditions and seasonal influence on measured parameters. 


\section{Experimental Program}

\section{$\underline{\text { Site Description }}$}

Anchorage Regional Landfill (ARL) is a modern landfill with Subtitle D liner systems (barriers and leachate collection systems). ARL has a total of 8 cells and has been operational since 1992. ARL does not have an active gas collection system. Operational and climatic statistics for ARL are presented in Table 1. ARL has relied on deep excavations (on the order of $25 \mathrm{~m}$ ) from a planning standpoint for development of cells. This has served two purposes; the first is maximization of airspace within the available footprint, the second relates to increased structural stability of the interim and completed landfill, particularly for seismic activity. Cell sizes were on the order of 6 to 8 ha due to airspace requirements, which yielded approximately 2.3 million $\mathrm{m}^{3}$ capacity. Cell construction has progressed on a 4 to 6 year schedule based on incoming acceptance rates. Cells were developed to provide adequate storage of waste for a filling period of 5 years at any given time. The average yearly intake typically fills two lifts over the average cell dimensions with average lift thicknesses of 3 to $4 \mathrm{~m}$ and waste unit weights of $5.2 \mathrm{kN} / \mathrm{m}^{3}$. Site records indicate that placement varied on a semi-annual basis between higher elevation and lower elevation cells. Placement in higher elevation cells coincidentally tended to be concentrated during winter seasons. In all cases, wastes have been placed at lower elevation areas during significant wind events to shelter waste placement operations. The waste placement practices resulted in alternating winter/summer lifts in a vertical sequence in a given cell. Depending on the start date of placement of lifts, underlying lifts were often buried in a frozen or cooled state and insulated by the overlying lift.

\section{Table 1. Operational and Climate Statistics for ARL}

\begin{tabular}{|c|c|}
\hline Parameter & Value \\
\hline Design waste placement area (ha) & 67 \\
\hline Design volume $\left(\mathrm{m}^{3}\right)$ & $32,360,000$ \\
\hline Average waste intake (t/year) & 317,000 \\
\hline Waste placement rate (m/year) & $4-7$ \\
\hline Average waste column height (m) & 26.5 \\
\hline Leachate pumped ( $\mathrm{m}^{3} / \mathrm{m}^{2}$-year) & 0.068 \\
\hline Gas produced (m gas $/ \mathrm{m}^{3}$ waste/year) & $0.80^{1}$ \\
\hline Number of instrumented cells & 4 \\
\hline Total temperature sensors & 205 \\
\hline Total gas sensors & 93 \\
\hline Climatic zone and description $^{2}$ & Cold temperate boreal zone, oceanic boreal climate \\
\hline Average daily high temperature $\left({ }^{\circ} \mathrm{C}\right)^{3}$ & 6.2 \\
\hline Average daily low temperature $\left({ }^{\circ} \mathrm{C}\right)^{3}$ & -1.5 \\
\hline Average daily temperature $\left({ }^{\circ} \mathrm{C}\right)^{3}$ & 2.3 \\
\hline Annual normal precipitation $(\mathrm{mm})^{3}$ & 408 \\
\hline Annual normal snowfall $(\mathrm{mm})^{3}$ & 1793 \\
\hline Mean annual earth temperature $\left({ }^{\circ} \mathrm{C}\right)^{4}$ & 5.4 \\
\hline \multicolumn{2}{|c|}{$\begin{array}{l}{ }^{1} \text { estimated amount based on numerical simulation for medium-dry/dry conditions, gas not actually collected sinc } \\
\text { gas collection system is not installed } \\
{ }^{2} \text { based on Landsberg et al. (1966) } \\
{ }^{3} \text { from NCDC (2004) } \\
{ }^{4} \text { based on reference measurements at site }\end{array}$} \\
\hline
\end{tabular}


Field Measurements and Analysis

Temperature and gas data were collected in multiple cells using horizontal and vertical arrays at ARL since 2002. Measurements were taken at discrete locations in various components of the landfill system including below liner, within liner, within waste mass, within interim cover, and within subgrade soils near the perimeter of the landfill. Sensors were placed in linear arrays in horizontal and vertical configurations. The arrays consisted of Type $\mathrm{K}$ thermocouple wire encased within flexible PVC tubing (for temperature measurements) and copper refrigeration tubing with gas sampling ports at the terminal end (for gas measurements). The length of horizontal sensor arrays was $206 \mathrm{~m}$ with 8 sensors on each array. The length of vertical sensor arrays ranged from 18 to $48 \mathrm{~m}$ and the number of sensors on each vertical array ranged from 4 to 21 . Temperature measurements have been taken weekly and gas measurements have been taken monthly.

Data analysis in this investigation included determination of spatial and temporal variation of temperatures and gas compositions within wastes. Effects of climatic and operational conditions were analyzed. Rates of temperature change were determined. Timing for onset of temperature increases and gas production were identified. Temperature envelopes depicting limiting maxima and minima with depth were developed for the waste mass. The envelopes were used to estimate heat content $(H C)$ of the waste mass (Yesiller et al. 2005). Instantaneous vertical thermal gradients were calculated as the quotient of temperature difference between two adjacent sensors and vertical distance between the sensors for a single monitoring event. In addition, frost depths within the waste mass were determined as the $0^{\circ} \mathrm{C}$ isotherm using measured temperatures and also using the modified Berggren equation as described by Andersland and Ladanyi (1994). HC values were determined using the method that was developed specifically for analysis of wastes, whereas frost depths were determined using methods that were developed for analysis of soils.

\section{Numerical Modeling}

Finite element analysis was used to conduct a parametric study of the influence of waste filling practices on decomposition and resulting heat generation in wastes. A mesh containing 3-D quadrilateral brick elements was constructed for the model. ABAQUS ${ }^{\circledR}$ FEA software (Version 6.5) was used in the analysis. The material properties used in the analysis are presented in Table 2. Simulations were conducted using transient thermal analysis with boundary conditions prescribed as a sinusoidal temperature function at the ground surface and a stable temperature at the far-field boundary at great depth. A temperature envelope generated using measured temperatures at depth at a reference control site was extrapolated to the surface to provide an idealized sinusoidal (seasonal) ground surface temperature function that had a mean value of $5.4^{\circ} \mathrm{C}$ and an amplitude of $9.9^{\circ} \mathrm{C}$. The far-field boundary at depth was specified as a constant temperature of $5.4^{\circ} \mathrm{C}$ at a depth $75 \mathrm{~m}$ below the base of the waste mass. A step-function was used to model heat generation due to decomposition as a function of temperature. For temperatures equal to or below $0^{\circ} \mathrm{C}$, zero heat generation was used and for temperatures above $0^{\circ} \mathrm{C}$, a step function of heat generation rate with time was used. Heat generation rates were modeled as $2.5 \mathrm{~W} / \mathrm{m}^{3}$ 
(first 120 days after waste placement) and $0.08 \mathrm{~W} / \mathrm{m}^{3}$ (remaining time). Waste filling rates were selected in accordance with ranges consistent with site operation. Variable rates of filling and lift thicknesses (including variable thickness of frozen waste layers) were modeled to investigate the effects of filling sequences (rates respective to seasons) on resulting thermal conditions and decomposition potential for wastes.

Table 2. Material Properties for FEA Modeling

\begin{tabular}{c|c|c}
\hline \hline Parameter & Waste & Soil \\
\hline Unit weight $\left(\mathrm{kN} / \mathrm{m}^{3}\right)$ & 5.2 & 21.0 \\
\hline Thermal conductivity $(\mathrm{W} / \mathrm{mK})$ & 0.23 & 2.35 \\
\hline Volumetric heat capacity $\left(\mathrm{kJ} / \mathrm{m}^{3} \mathrm{~K}\right)$ & 719 & 1783 \\
\hline Thermal diffusivity $\left(\mathrm{m}^{2} / \mathrm{s}\right)$ & $3.2 \times 10^{-7}$ & $1.3 \times 10^{-6}$ \\
\hline Latent Heat $(\mathrm{kJ} / \mathrm{kg})$ & 32.1 & 1.7 \\
\hline
\end{tabular}

\section{Results}

\section{Field Measurements}

Effects of overlying waste filling are demonstrated in Fig. 1 for two horizontal arrays. Wastes were placed above the 156 and $206 \mathrm{~m}$ sensors in summers of 2003 and 2004 for array Cell 4-5A. Sensors at 16-46 m were covered in fall 2003. Wastes were placed above the 106-206 m sensors in spring 2003 for array Cell 4-5B. Sensors at 156 and $206 \mathrm{~m}$ were damaged during waste placement, terminating their functionality. The shorter sensors were covered incrementally over the next year. Total depths of overlying wastes ranged from 0 to $9 \mathrm{~m}$. Amplitudes of temperature fluctuations dampen upon placement of overlying wastes. Steady temperatures of approximately 19 to $21^{\circ} \mathrm{C}$ and 15 to $18^{\circ} \mathrm{C}$ were measured in Cell 4-5A and Cell 4-5B, respectively. Different responses were observed for placement during heating (spring and summer) and cooling (fall and winter) seasons. Relative to placement temperatures, final temperatures may be warmer or cooler due to placement season. Uncovered sensors continue to indicate significant seasonal temperature fluctuations including freezing during winter seasons.
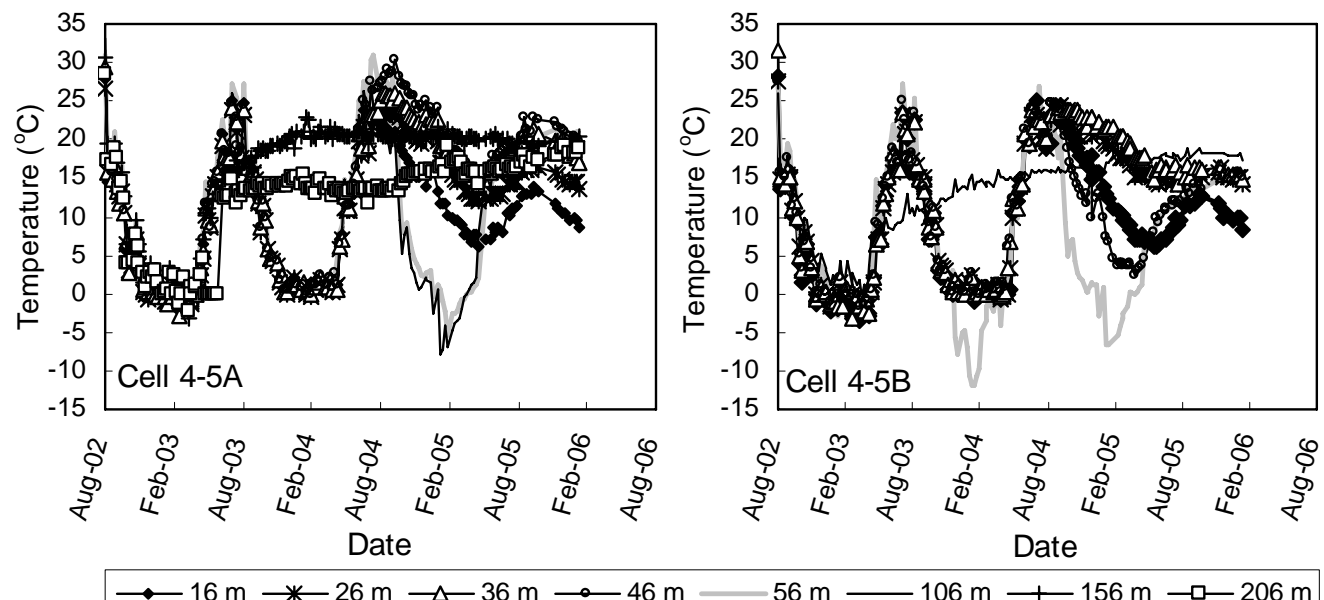

$\multimap-16 \mathrm{~m} \rightarrow 26 \mathrm{~m} \neg-36 \mathrm{~m} \multimap 46 \mathrm{~m} \longleftarrow 56 \mathrm{~m} \longleftarrow 106 \mathrm{~m} \longrightarrow 156 \mathrm{~m} \longrightarrow 206 \mathrm{~m}$

Figure 1. Temperature vs. time for horizontal arrays. 
Effects of waste age and initial placement temperature on resulting waste temperatures are presented in Fig. 2 for three vertical arrays. For all three arrays, wastes near the surface (beneath interim cover) underwent seasonal temperature variations whereas steady temperatures were reached at depth. Temperature variations in wastes with ages 3 to 18 years are presented in Fig. 2a. Maximum steady elevated temperatures of approximately $35^{\circ} \mathrm{C}$ were measured at a depth of 32 $\mathrm{m}$ for 13-year-old wastes that were placed in summer. Temperatures of both over and underlying wastes were less than the peak value. Temperature variations in wastes with ages 3 to 4 years are presented in Fig. 2b. Fluctuating, yet somewhat elevated temperatures were measured between 0 and $1.3 \mathrm{~m}$. Elevated steady temperatures were measured below $2.3 \mathrm{~m}$. Maximum steady temperatures (approximately $21^{\circ} \mathrm{C}$ ) were measured at $8.3 \mathrm{~m}$, whereas minimum steady temperatures (approximately $14^{\circ} \mathrm{C}$ ) were measured at $18.3 \mathrm{~m}$. The upper range of steady temperatures was observed for wastes placed during spring to summer 2002 whereas the lower range of steady temperatures was observed for wastes placed during winter to summer 2001. Results from an array containing significant fraction of waste placed in a frozen condition is presented in Fig. 2c. A frozen waste band with a thickness of $7 \mathrm{~m}$ was placed between November 2003 and January 2004. Wastes underlying the frozen band were placed in late summer 2002 (21 to $23 \mathrm{~m}$ ) and late summer 2003 (16 to 20 $\mathrm{m})$. A layer of waste was placed above the frozen wastes between April and July 2004 to a thickness of $8 \mathrm{~m}$. The mid-region of the frozen waste band remains at subfreezing temperatures 2 years subsequent to placement at depths between 12.9 and $14.9 \mathrm{~m}$ (Fig. 2c). However, the top and bottom regions of the frozen waste band began to thaw within 2 months of placement. Stable temperature trends have developed ranging from -1 to $15^{\circ} \mathrm{C}$. Even though the temperatures of the remaining frozen wastes appear to have stabilized at $-1^{\circ} \mathrm{C}$, eventual thawing is expected in the long term. In general, final waste temperatures increased with increasing placement temperature. However, the wastes placed near the vicinity of the frozen waste band (Fig. 2c) were affected by the presence of this cold mass and did not reach temperatures as high as comparable wastes in other cells (Figs. 2a and 2b).

A comparison of temperature envelopes with depth for vertical arrays is presented in Fig. 3. Locations of bottom liners are marked with dashed lines in the plots. High seasonal temperature variations near the surface and steady temperatures at depth were observed. Such temperature envelopes in wastes typically display a bulb of elevated temperatures indicating high heat production towards the center of the landfill (Yesiller et al. 2005). This trend was observed in arrays Cell 1M and Cell 1A whereas distinctly cooler temperatures were associated with the envelope for frozen wastes in array Cell 6 displaying reverse concavity.

The envelopes were used to predict $H C$ with depth for a given location. $H C$ determined from vertical arrays throughout ARL range from -8.2 (for 2-year-old waste at a depth of $11.9 \mathrm{~m}$ for the vertical array placed in frozen wastes) to $+25.9^{\circ} \mathrm{C}$ day/day (for 13-year-old waste at a depth of $32 \mathrm{~m}$ for a vertical array placed in summer). A negative $H C$ indicates that the waste temperatures were below temperatures at equivalent depth for unheated conditions. 


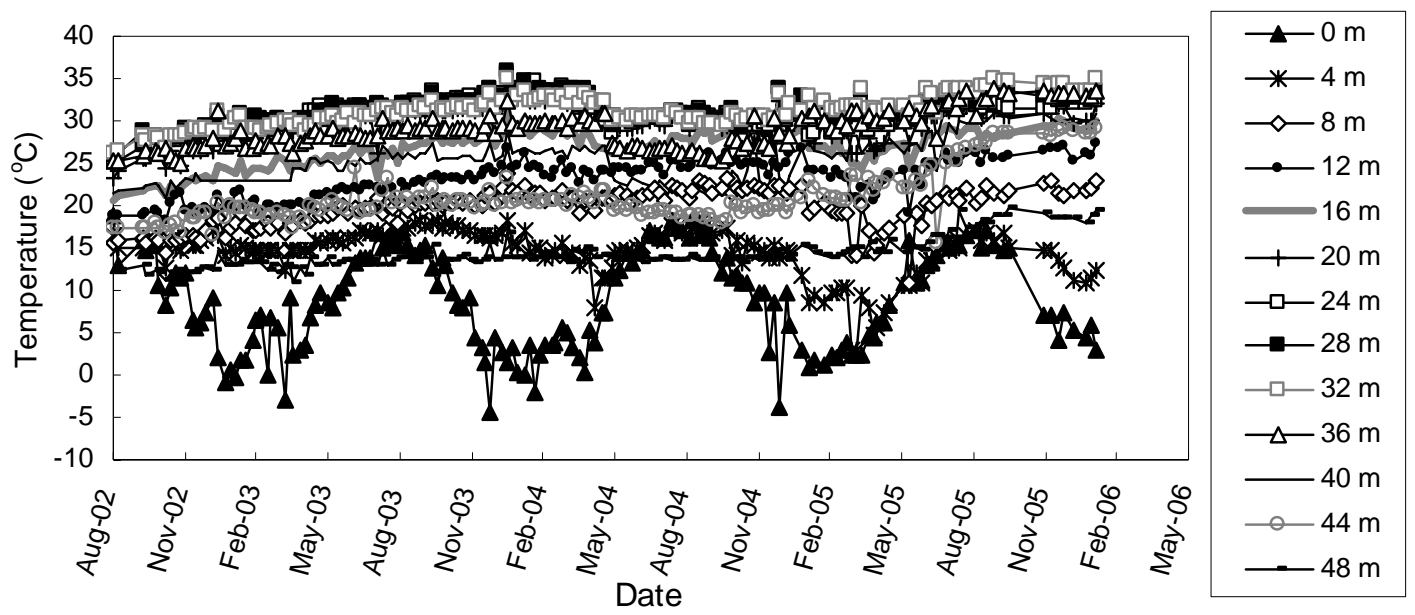

(a) Array Cell $1 \mathrm{M}$
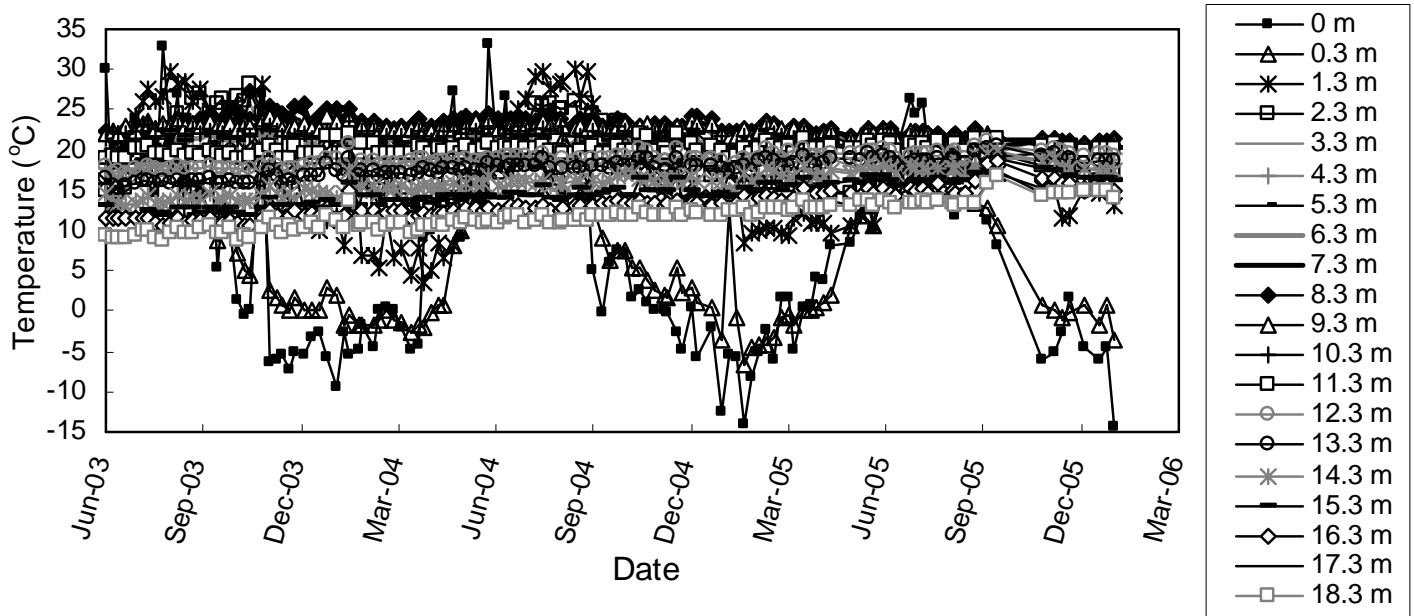

(b) Array Cell 1A

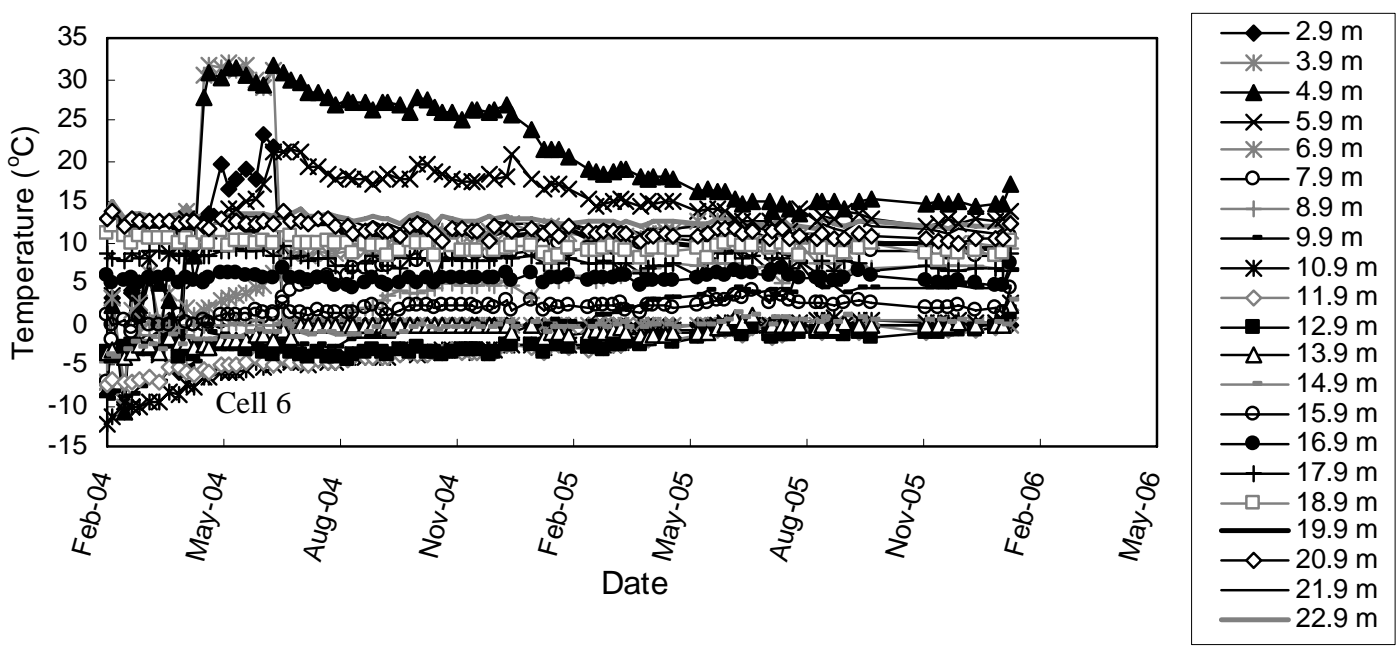

(c) Array Cell 6

Figure 2. Plots of temperature vs. time for vertical arrays. 

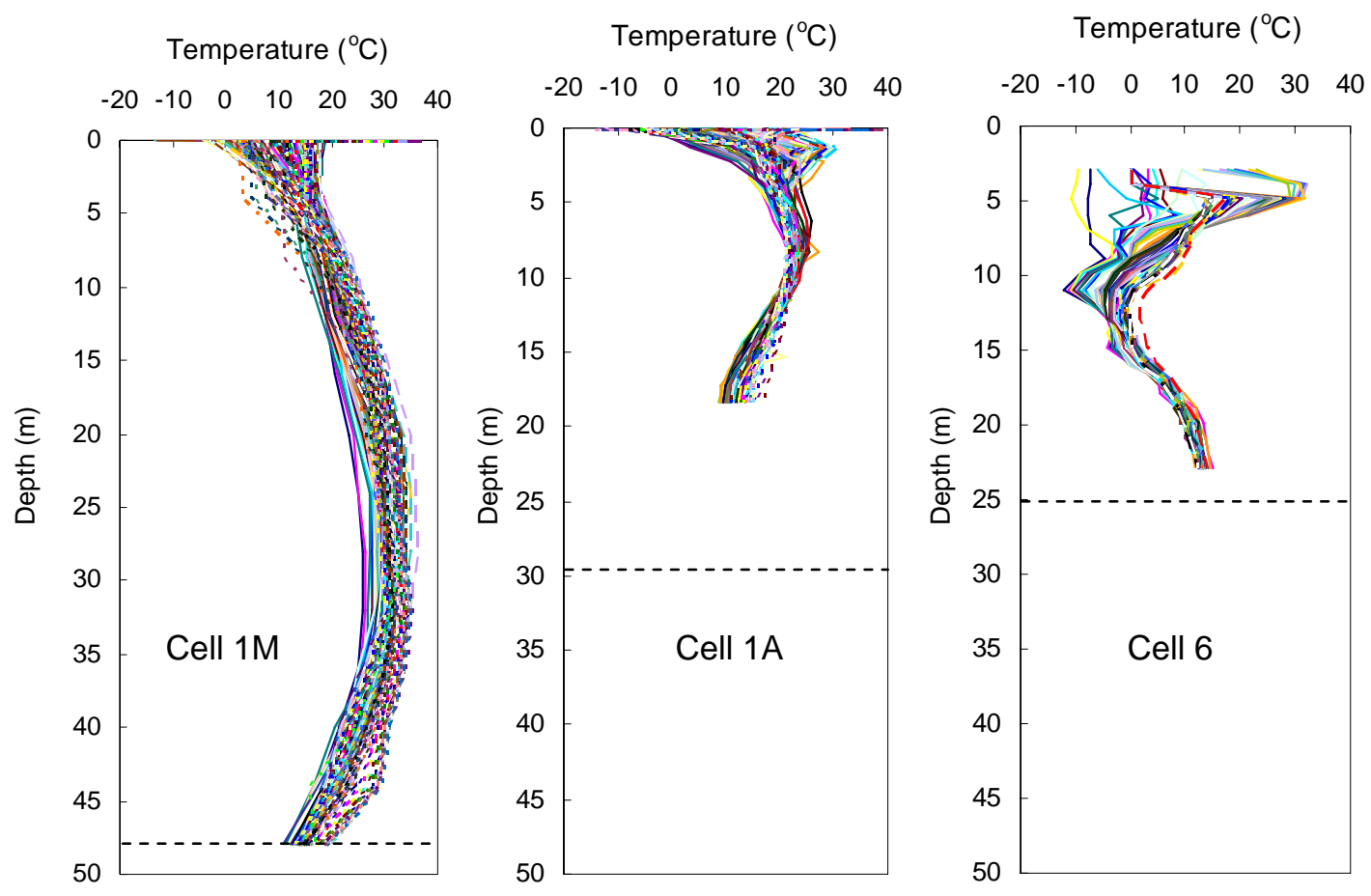

Figure 3. Temperature envelopes with depth.

Frost depths for wastes placed in an unfrozen condition, measured at the site as the $0^{\circ} \mathrm{C}$ isotherm, ranged from 0.7 to $1.3 \mathrm{~m}$. The wastes at these measurement locations were overlain by approximately $0.5 \mathrm{~m}$ of soil cover. Measurements in the native soils at a control reference location at the site indicated a frost depth of $2.2 \mathrm{~m}$. The lower frost depths for wastes are attributed to lower thermal diffusivity in comparison to the site soils and the presence of heat generation in the wastes.

Instantaneous thermal gradients were calculated to range from -73 to $+60^{\circ} \mathrm{C} / \mathrm{m}$ (positive indicates downward heat flow) for the wastes. In general, maximum gradients were present near the ground surface. The average absolute thermal gradient for the wastes was $2.5^{\circ} \mathrm{C} / \mathrm{m}$.

Measurements of gas composition demonstrate a delay in onset of production of methane between 3 to 4 years after waste placement. Approximately 3 years after waste placement, the measured gas compositions reached $40-50 \% \mathrm{CH}_{4}, 40-50 \% \mathrm{CO}_{2}$, and negligible $\mathrm{O}_{2}$. Increases in waste temperatures were measured within weeks or months of waste placement, well before onset of methane production. Regulatory testing at ARL indicated a delay in onset of methane generation. In discrete sampling events temperatures of approximately $10^{\circ} \mathrm{C}$ and gas compositions of $20-30 \% \mathrm{CO}_{2}$ and $70-80 \% \mathrm{~N}_{2}$ were measured. It was estimated from the regulatory testing that onset of methane generation occurred approximately 4 years subsequent to waste placement. 


\section{Numerical Predictions}

Initially, a comparison between measured and predicted temperatures was conducted for Cell 6 to validate the effectiveness of the FEA model in predicting waste temperatures (Fig. 4). Generally, good agreement was observed between measured and predicted temperatures at the various measurement depths as shown by the results for shallow, middle, and great depths presented in Fig. 4. Then, a series of simulations was conducted using variable seasonal waste placement strategies. Results of the simulations are presented in Fig. 5 as series of tautochrones (forming temperature envelopes with depth) for weekly determinations of temperatures over a 3-year period after completion of waste placement. The results of this parametric study indicated that maximum stable temperatures were obtained for conditions of exclusively summer waste placement (Fig. 5a). Conversely, minimum temperatures were obtained for exclusively winter waste placement (Fig. 5b). When alternating summer and winter placements were used, the maximum stable temperatures varied as a function of the fraction of frozen wastes. The simulation with the lowest frozen thickness (one 3-m-thick lift of frozen waste) resulted in the maximum stable temperatures for multi-season waste placement conditions (Fig. 5c). Additional frozen thickness (two 3-m-thick lifts of frozen waste) resulted in notably lower temperatures after a 3-year simulation period (Fig. 5d). Results of this numerical investigation suggest that ultimate stable temperatures are strongly influenced by seasonal waste placement conditions. The results indicated the detrimental effects of burying frozen wastes before thawing has occurred on the generation of thermal conditions conducive to microbial decomposition.

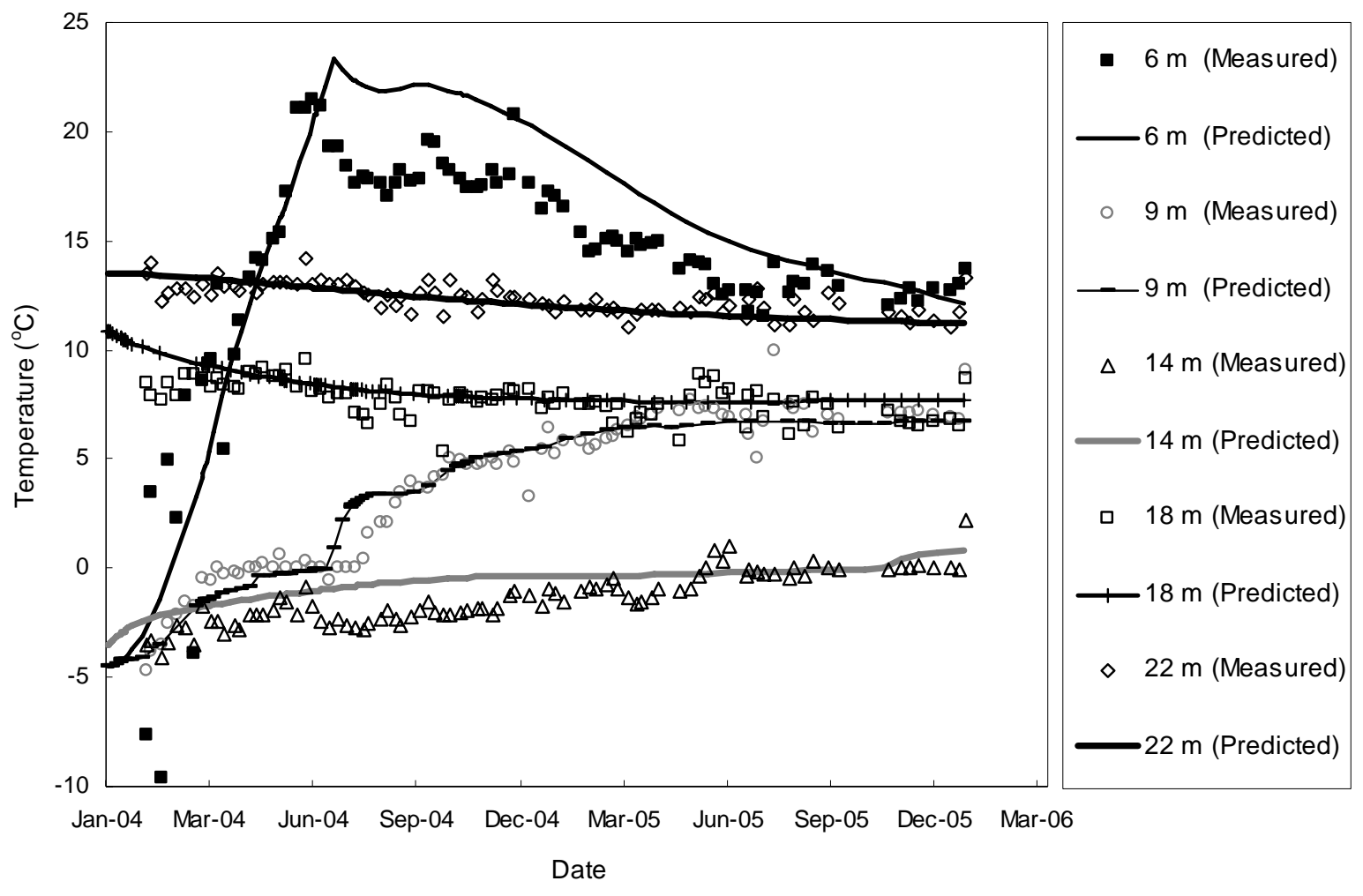

Figure 4. Validation of numerical model. 


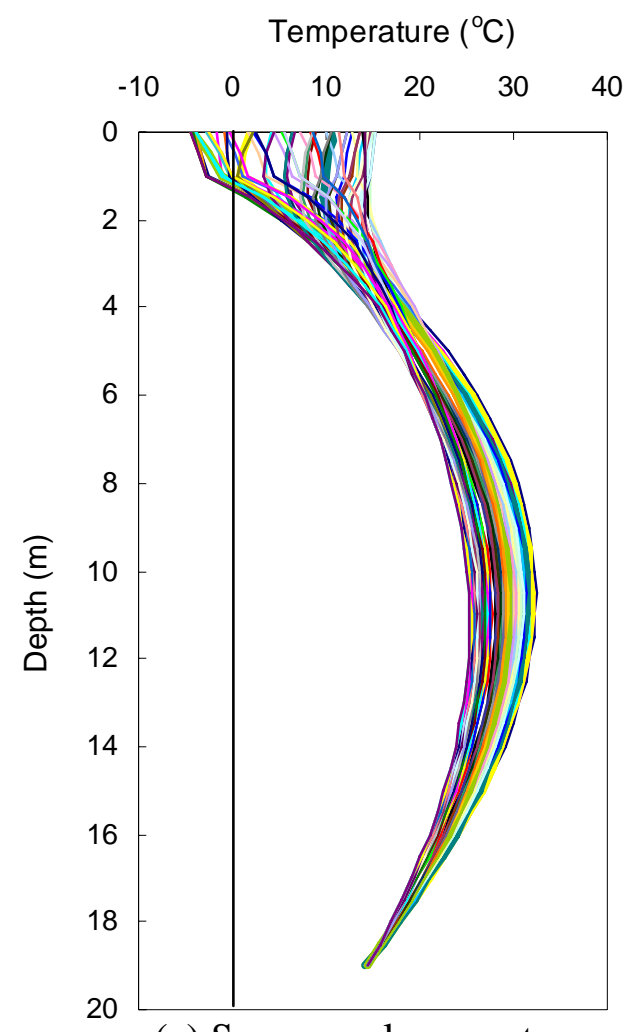

(a) Summer placement

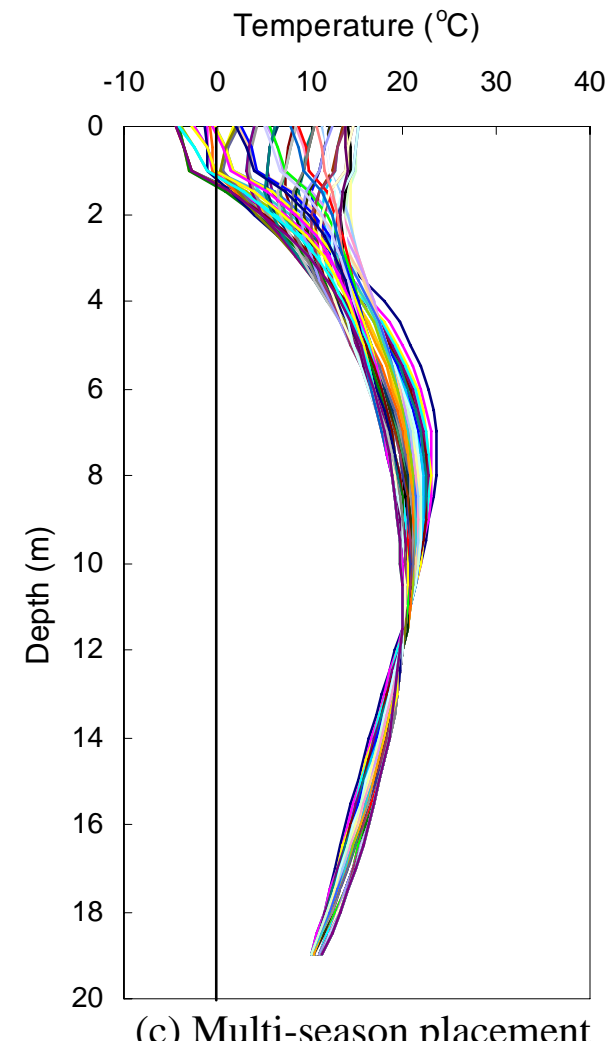

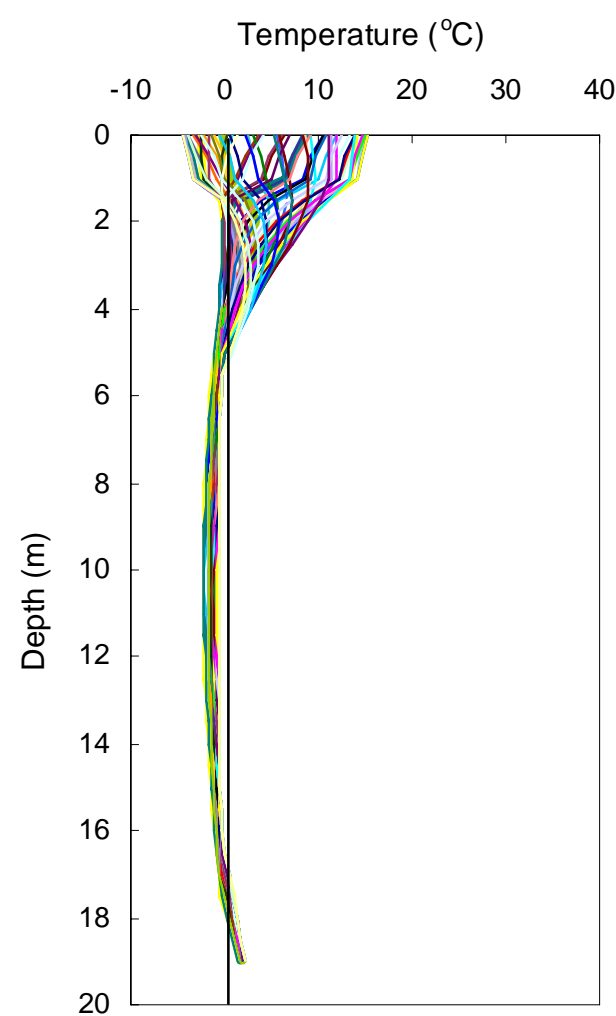

(b) Winter placement
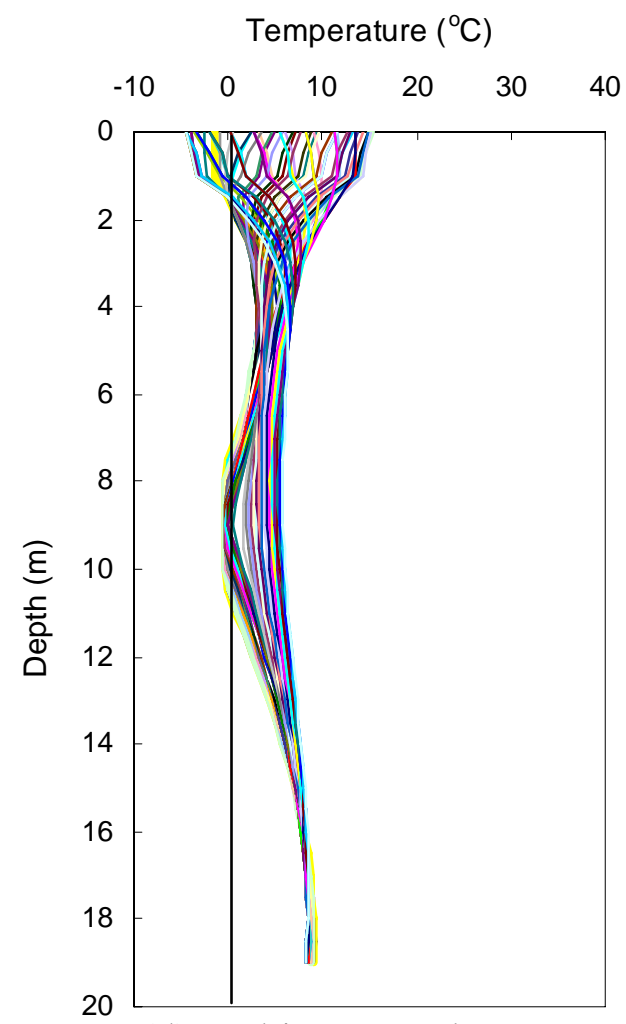

(d) Multi-season placement

Figure 5. Results from Parametric Study. 


\section{Conclusions}

Conclusions provided below were drawn based on the field measurements and numerical modeling used in this investigation:

1 - Maximum stable temperatures with a wide range $\left(-1\right.$ to $\left.+35^{\circ} \mathrm{C}\right)$ were observed in wastes in Anchorage, Alaska. The high variation resulted from age of waste and waste placement temperature. Stable temperatures reached over $30^{\circ} \mathrm{C}$ for wastes greater than 10 years old that were placed during summer.

2 - The central core of a 7 m-thick frozen waste band remains frozen 2 years after placement at a depth of $13 \mathrm{~m}$ due to insulating effects of over and underlying wastes.

3 - Temperature envelopes with depth indicated high temperature variation near the surface similar to seasonal air temperature variation and relatively steady temperatures with depth. $H C$ values ranged from -8.2 (for 2-year-old waste at a depth of $11.9 \mathrm{~m}$ for the vertical array placed in frozen wastes) to $+25.9^{\circ} \mathrm{C}$-day/day (for $13-$ year-old waste at a depth of $32 \mathrm{~m}$ for a vertical array placed in summer).

4 - The measured frost depths in waste ranged from 0.7 to $1.3 \mathrm{~m}$ and were less than that for native soil at the landfill site due to thermal properties of wastes and heat generation in wastes.

5 - Instantaneous thermal gradients were calculated to range from -73 to $+60^{\circ} \mathrm{C} / \mathrm{m}$.

6 - Onset of gas generation is delayed 1 to 2 years due to dry and cool conditions at the site (compared to warmer and more humid climates) and occurs 3 to 4 years after waste placement. It is recommended that wastes be placed in as thin lifts as possible under frozen conditions for promoting higher temperatures that lead to enhanced decomposition conditions.

\section{Acknowledgement}

This study was supported by the National Science Foundation (GOALI Grant: CMS-9813248 and SGER Grant: CMS-0301032). Assistance of Anchorage Regional Landfill is greatly appreciated.

\section{References}

Andersland, O. B. and Ladanyi, B. (1994). An introduction to frozen ground engineering, Chapman and Hall, New York.

Cecchi, F., Pavan, P., Musacco, A., Mata-Alvarez, J., and Vallini, G. (1993). "Digesting the organic fraction of municipal solid waste: Moving from mesophilic $\left(37^{\circ} \mathrm{C}\right)$ to thermophilic $\left(55^{\circ} \mathrm{C}\right)$ conditions," Waste Management \& Research, ISWA, 11, 403-414.

DeWalle, F. B., Chian, E. S. K., and Hammerberg, E. (1978). "Gas production from solid waste in landfills,” Journal of the Environmental Engineering Division, ASCE, 104, EE3, 415-432.

Hanson, J. L., Yesiller, N., and Kendall, L. A. (2005). "Integrated Temperature and Gas Analysis at a Municipal Solid Waste Landfill," Proceedings of the $16^{\text {क }}$ ICSMGE, Millpress Science Publishers, Rotterdam, the Netherlands, Vol. 4, 2265-2268.

Hartz, K. E., Klink, R. E., and Ham, R. K. (1982). "Temperature effects: Methane generation from landfill samples,” Journal of Environmental Engineering, ASCE, 108, EE4, 629-638.

Landsberg, H. E., Lippmann, H., Paffen, K. H., and Troll, C. (1966). World maps of climatology, $3^{\text {rd }}$ Edition, Rodenwaldt, E. and Jusatz, H. J., eds., Springer-Verlag, Berlin.

Mata-Alvarez, J. and Martinez-Viturtia, A. (1986). "Laboratory simulation of municipal solid waste fermentation with leachate recycle," J. Chem. Tech. Biotechnol., SCI, 36, 547-556.

NCDC (2004). "Climate database," National Climatic Data Center, last accessed: 1 June 2004, http://www.ncdc.noaa.gov/.

Rees, J. F. (1980). "The fate of carbon compounds in the landfill disposal of organic matter," J. Chem. Tech. Biotechnol., Society of Chemical Industry, 30, 161-175.

Tchobanoglous, G. Theisen, H., and Vigil, S. A. (1993). Integrated solid waste management: Engineering principles and management issues, McGraw Hill, Inc., New York, NY.

Yesiller, N., Hanson, J. L., and Liu, W.-L., (2005). "Heat Generation in Municipal Solid Waste Landfills,” Journal of Geotech. and Geoenvironmental Engineering, ASCE, 131, 11, 1330-1344. 